\title{
Evaluation of Inhibitory Activities of UK-2A, an Antimycin-Type Antibiotic, and Its Synthetic Analogues against the Production of Anti-inflammatory Cytokine IL-4
}

\author{
Yoshinosuke Usuki, Saho Ishii, Minako Ijiri, Ken-Ichi
}

Yoshida, Tetsuya Satoh, Satoru Horigome, Izumi Yoshida,

Takashi Mishima, Ken-Ichi Fujita

\begin{tabular}{|c|c|}
\hline Citation & Journal of Natural Products. 81(11); 2590-2594 \\
\hline Issue Date & $2018-11-12$ \\
\hline Type & Journal article \\
\hline Text version & author \\
\hline $\begin{array}{l}\text { Supporting } \\
\text { Information }\end{array}$ & $\begin{array}{l}\text { The Supporting Information is available free of charge on the ACS Publications } \\
\text { website at https://doi.org/10.1021/acs.jnatprod.8b00559. }\end{array}$ \\
\hline Right & $\begin{array}{l}\text { This document is the Accepted Manuscript version of a Published Work that appeared } \\
\text { in final form in Journal of Natural Products, copyright } \odot \text { American Chemical Society } \\
\text { after peer review and technical editing by the publisher. To access the final edited and } \\
\text { published work see https://doi.org/10.1021/acs.jnatprod.8b00559. }\end{array}$ \\
\hline DOI & 10.1021/acs.jnatprod.8b00559 \\
\hline
\end{tabular}

Self-Archiving by Author(s)

Placed on: Osaka City University Repository

USUKI Y, ISHII S, IJIRI M, YOSHIDA KI, SATOH T, HORIGOME S, YOSHIDA I, MISHIMA T, \& FUJITA KI. (2018). Evaluation of Inhibitory Activities of UK-2A, an Antimycin-Type Antibiotic, and Its Synthetic Analogues against the Production of Anti-inflammatory Cytokine IL-4. Journal of Natural Products. 81, 2590-2594. doi:10.1021/acs.jnatprod.8b00559 
Evaluation of Inhibitory Activities of UK-2A, an Antimycin-type Antibiotic, and its Synthetic Analogues against the Production of Anti-inflammatory Cytokine IL-4

Yoshinosuke Usuki, ${ }^{*}{ }^{\dagger}$ Saho Ishii, ${ }^{\dagger}$ Minako Ijiri,${ }^{\dagger}$ Ken-Ichi Yoshida,${ }^{\dagger}$ Tetsuya Satoh,${ }^{\dagger}$ Satoru Horigome ${ }^{\ddagger}$ Izumi Yoshida, ${ }^{\ddagger}$ Takashi Mishima ${ }^{\ddagger}$ and Ken-Ichi Fujita ${ }^{*} \S$

${ }^{\dagger}$ Department of Chemistry, Graduate School of Science, Osaka City University, 3-3-138

Sugimoto, Sumiyoshi, Osaka 558-8585, Japan

†Saito Laboratory, Japan Food Research Laboratories, 4-41 Saito-asagi 7-chome, Ibaraki-shi, Osaka 567-0085, Japan

${ }^{\S}$ Department of Biology, Graduate School of Science, Osaka City University, 3-3-138 Sugimoto, Sumiyoshi, Osaka 558-8585, Japan 
The inhibitory activities of the antimycin-class antibiotics, UK-2A, antimycin A, and splenocin B, against the production of anti-inflammatory cytokine IL-4, which is related to IgE-mediated allergic responses in rat basophilic leukemia (RBL-2H3) cells, were evaluated. Although antimycin A and splenocin B showed cytotoxicity at concentrations at which IL-4 release from the cells was restricted, UK-2A was found to restrict IL-4 release without cytotoxicity. Three UK-2A analogues (4-6) were then synthesized and assessed. Compound 5 restricted IL-4 release dosedependently without cytotoxicity, and its effect was more potent than that of UK-2A. 
UK-2A (1), an antifungal antibiotic produced by Streptomyces sp. 517-02, which was first isolated in 1996 from a soil sample collected at Sugimoto campus of Osaka City University, is similar to antimycin A (2) in its structure and inhibitory activity against electron transport in mitochondrial complex III. ${ }^{1-4}$ Splenocin B (3), another antimycin-type depsipeptide, has recently been found to demonstrate a potent anti-inflammatory effect at low nanomolar concentrations owing to the suppression of the production of Th-2 cytokines, such as interleukin (IL)-5 and IL13, by OVA-stimulated splenocytes. ${ }^{5}$ This discovery highlights the potential of the antimycin subfamily as anti-inflammatory agents related to the suppression of Th-2 cytokine release, and as research probes for analyzing the function of mitochondrial electron transport chains. ${ }^{6,7}$

Molecules of the antimycin subfamily comprise nine-membered dilactone rings linked via an amide bond to an aromatic acid moiety (Figure 1). Splenocins and antimycins contain 3formamido salicylic moieties, whereas UK-2A possesses a 3-hydroxy-4-methoxy-picolinic moiety.

Splenocin B (3) is as effective as dexamethasone in inhibiting the production of Th-2 cytokines, and may be regarded as a hybrid molecule combining some of the structural features of UK-2A and antimycin A (the benzyl group at the $\mathrm{C} 2$ position in compound $\mathbf{3}$ has not been reported in antimycins). ${ }^{5}$ As an extension of our continuing studies on UK-2A, ${ }^{8-11}$ we have previously accomplished total synthesis of compound $3{ }^{12}$ This achievement prompted our interest in the biological evaluation of antimycin-class antibiotics.

In addition to IL-5 and IL-13, IL-4 is a B-cell growth factor and stimulates B-cell differentiation. ${ }^{13}$ IL-4 and IL-5 are essential for the production of IgE and eosinophilia, respectively. ${ }^{14}$ Conversely, IL-13 works together with IL-4 in producing biologic effects associated with allergic inflammation and defense against parasites. ${ }^{13}$ Therefore, this study focuses 
on inhibitory activities of these antimycin-class antibiotics against the production of antiinflammatory cytokine IL-4, which is related to IgE-mediated allergic responses. Herein, we report our results from these endeavors.

We first examined the effects of compounds 1-3 on levels of anti-inflammatory cytokine IL-4 in mouse monoclonal anti-dinitrophenyl (DNP)-IgE-stimulated rat basophilic leukemia (RBL2H3) cells, largely based on a previously reported method. ${ }^{15} \mathrm{IL}-4$ release from RBL-2H3 cells was restricted in cells treated with antimycin A and splenocin B at concentrations > $20 \mathrm{nM}$ (Figure 2A). To the best of our knowledge, this is the first report on the inhibitory activity of antimycin A against the production of IL-4. Conversely, UK-2A significantly restricted this release at concentrations $>2,000 \mathrm{nM}$. These results indicate that the inhibitory effect of UK-2A against IL4 release is weaker than that of antimycin A and splenocin B.

Cell viability was also assayed for evaluating cytotoxicity of compounds $\mathbf{1}-\mathbf{3}$ on RBL-2H3 cells after drug exposure for $24 \mathrm{~h}$ using a protocol previously reported. ${ }^{16}$ Antimycin A and splenocin B significantly inhibited cell proliferation at concentrations $>5$ and $>40 \mathrm{nM}$, respectively (Figure 2B). However, UK-2A did not exhibit any growth inhibitory effect up to 4,000 nM. Cytotoxicities of antimycin A and UK-2A established herein are similar to those previously established using other cell lines, including mouse leukemia P-388, mouse melanoma B-16, human oral epidermoid carcinoma KB, and human colon adenocarcinoma COLO201 cells. ${ }^{1}$ Specifically, although antimycin A and splenocin B showed cytotoxicity at concentrations at which IL-4 release was restricted, UK-2A restricted IL-4 release without cytotoxicity.

To explore the structure-activity relationship among UK-2A analogues, three hybrid molecules (4-6) with combined structural features of UK-2A and antimycin $\mathrm{A}_{3}$ were prepared by methods 
described previously (Figure 3). ${ }^{9}$ The effects of compounds 4-6 on levels of anti-inflammatory cytokine IL-4 in DNP-IgE-stimulated RBL-2H3 cells was evaluated by the above described methods. IL-4 release from RBL-2H3 cells was dose-dependently restricted in cells treated with compound 5 at concentrations $<125 \mathrm{nM}$ (Figure S1). Maximum restriction was observed at 125$4000 \mathrm{nM}$. The $\mathrm{IC}_{50}$ value was calculated to be $41.32 \mathrm{nM}$ (Table 1) based on the data of Figure S1. These results indicate that the inhibitory effect of compound $\mathbf{5}$ on IL-4 release is ca. 30-times stronger than that of UK-2A ( $\mathrm{IC}_{50}=1377 \mathrm{nM}$, Figure S1), suggesting that the 3-formamido salicylic moiety significantly contributes to restriction of IL-4 release from RBL-2H3 cells. Furthermore, the restriction levels of compound $\mathbf{5}$ were almost constant at concentrations $>125 \mathrm{nM}$ possibly indicating that the limited number of target molecules were saturated by excess 5 . Although similar results were reported previously, ${ }^{17}$ the mechanism was not provided. Possible targets for compound 5 include intracellular signaling molecules or protein kinases in cascades inducing IL4 release, IgE antibodies on cell membrane, or antigens to be bound to the antibodies. Compound 4 significantly and dose-dependently restricted the release of IL-4, and maximum inhibition was observed at 4,000 nM (Figure S1), indicating that the activity of compound 4 was similar to that of UK-2A. Compound $\mathbf{6}$ dose-dependently restricted the release at lower concentrations, i.e., < $1000 \mathrm{nM}$. As the restrictive effects were weak, $\mathrm{IC}_{50}$ value was not determined. However, the maximum restriction was observed at $1000 \mathrm{nM}$. The restriction was slightly weakened at higher concentrations $>2000 \mathrm{nM}$ (Figure S1). This indicates that the substituent at the $\mathrm{C} 2$ position on the nine-membered dilactone ring moiety itself affects restriction of IL-4 release from RBL-2H3 cells.

Cytotoxicity of compounds 4-6 on RBL-2H3 cells after drug exposure for $24 \mathrm{~h}$ was also evaluated. ${ }^{16}$ Compounds $\mathbf{4 , 5}$, and $\mathbf{6}$ did not exhibit any growth inhibitory effect up to 4,000 nM (Figure S2). These results indicate that the methyl group at the $\mathrm{C} 8$ position on the nine-membered 
dilactone ring moiety contributes to the potency of cytotoxic activities, as reported previously. ${ }^{11}$ It is notable that compound $\mathbf{5}$ restricted IL-4 release without cytotoxicity.

The lack of the methyl group at the C8 position of antimycin A did not affect the inhibitory activity against mitochondrial respiration or cellular production of reactive oxygen species (ROSs). ${ }^{11}$ Although respiratory inhibition and ROSs have been suggested to contribute to the cytotoxicity of antimycins, little correlation between respiratory inhibition and cytotoxicity has been reported. For example, the 2-methoxy derivative at the 3-formamido salicylic moiety has been reported to be inactive as an inhibitor of cellular respiration but still exhibits cytotoxicity for anti-apoptotic Bcl-xL-over expressing cells and their mitochondria. ${ }^{18}$ Antimycin A interacts with the Bcl-2 homology domain 3-binding hydrophobic groove of Bcl-xL. ${ }^{18}$ These factors indicate the existence of another target for antimycin A. Further investigations are needed for revealing the role of the methyl group at the $\mathrm{C} 8$ position in antimycins cytotoxicity.

Respiratory inhibition caused by antimycin A was approximately 2.5 -fold greater than in the case of UK-2A in porcine renal proximal tubule LLC-PK1 cells. ${ }^{11}$ On the other hand, antimycin A induced cellular ROS generation whereas UK-2A did not when tested at similar concentrations. ${ }^{11}$ Although there seemed to be differences in the harmful effect of antimycin A and UK-2A towards mitochondria, UK-2A is also expected to induce cellular ROS generation when tested at extremely high concentrations 4,000 nM. Mitochondria-derived ROS generation dependent on partial ATP-synthase inhibition was reported to act as signal-transducing molecules that trigger NFKB-guided anti-inflammatory responses in the intestine of transgenic mice. ${ }^{19}$ Furthermore, the detection of live bacteria by macrophages was suggested to remodel and alter the activity of complexes in the mitochondrial electron transport chain, which is required for an optimal inflammatory response. ${ }^{20,21}$ However, these seemed to be different from the results 
obtained in this study. Namely, antimycin-class antibiotics might affect mitochondrial function related to electron transport chain thereby restricting the release of anti-inflammatory cytokines. As the ROS levels induced by antimycin A are possibly higher than those triggered in innate antiinflammatory responses originating from Toll-like receptors, physiological significance might differ between cytotoxic agent- and innate stimulation-induced ROS productions. Similar effects were reported in a plant derived polyphenol myricetin-induced oxidative stress. ${ }^{22}$ Myricetininduced ROS generation inhibited IL-2, IL-4, and IL-17 cytokine synthesis in murine T lymphocytes. ${ }^{22}$ However, in the case of compound 5, cytotoxicity was not observed up to 4000 nM. ROS generation by antimycin-class antibiotics depends on the respiratory inhibition at mitochondrial complex III as described above. Therefore, compound 5-induced ROS generation is expected to be relatively lower compared with antimycin A. This result suggests the existence of unknown targets of antimycin-class antibiotics for the restriction of IL-4 release, rather than ROS generation-dependent inhibition of the cytokine's release, observed in the case of the myricetin treatment. ${ }^{22}$

The present study demonstrates that compound $\mathbf{5}$ has anti-allergic effects in DNP-IgE-stimulated RBL-2H3 cells. Compound 5 showed no cytotoxicity on RBL-2H3 cells up to 4,000 nM, which is far higher than the concentration required for its IL-4 inhibitory activity. These results indicate that compound $\mathbf{5}$ has potential for further use in anti-inflammatory drug development. The mechanism of action of compound $\mathbf{5}$ is currently being studied in our laboratories. 


\section{Experimental Section}

General experimental procedures. ${ }^{1} \mathrm{H}$ and ${ }^{13} \mathrm{C}$ NMR spectra were recorded on either Bruker Avance 300 (300 and 75 MHz), Bruker Avance 400 (400 and 100 MHz), JEOL ECZ-400S (400 and $100 \mathrm{MHz}$ ), or Bruker Avance III 600 (600 and $150 \mathrm{MHz}$ ) instruments. Data were reported as follows: chemical shift, multiplicity $(\mathrm{s}=$ singlet, $\mathrm{d}=$ doublet, $\mathrm{t}=$ triplet, $\mathrm{q}=$ quartet, $\mathrm{m}=$ multiplet, and $\mathrm{br}=$ broad), coupling constant in $\mathrm{Hz}$, integration. Coupling constants were determined directly from ${ }^{1} \mathrm{H}$ and ${ }^{13} \mathrm{C}$ NMR spectra. Chemical shifts were reported in $\delta(\mathrm{ppm})$ values relative to $\mathrm{CHCl}_{3}$ $\left(\delta 7.26 \mathrm{ppm}\right.$ for ${ }^{1} \mathrm{H} \mathrm{NMR}$ and $\delta 77.0 \mathrm{ppm}$ for $\left.{ }^{13} \mathrm{C} \mathrm{NMR}\right)$ and to $\mathrm{Me}_{4} \mathrm{Si}\left(\delta 0.00 \mathrm{ppm}\right.$ for $\left.{ }^{1} \mathrm{H} \mathrm{NMR}\right)$. Mass spectra were obtained on a JEOL JMS-T100LP (DART, ESI) spectrometer. Infrared absorption spectra (IR) were measured by a JASCO FT/IR-4600 fourier transform infrared spectrometer. Optical rotations were measured on a JASCO P-2200 with path length of $1 \mathrm{dm}$ at ambient temperature; the concentrations are reported in $\mathrm{g} / \mathrm{dL}$.

All air- and moisture-sensitive reactions were carried out in a flame-dried, argon-flushed, twonecked flask sealed with rubber septa, and the dry solvents and reagents were introduced using a syringe. Tetrahydrofuran (THF) was fleshly distilled under an argon atmosphere from sodium benzophenone ketyl. Dichloromethane $\left(\mathrm{CH}_{2} \mathrm{Cl}_{2}\right)$ was fleshly distilled from phosphoric pentaoxide $\left(\mathrm{P}_{2} \mathrm{O}_{5}\right)$. Flash column chromatography was carried out on a Kanto Chemical silica gel 60N (spherical, neutral, 40-50 $\mu \mathrm{m}$ ), and pre-coated Merck silica gel plates (Art5715 Kieselgel 60F 254 , $0.25 \mathrm{~mm}$ ) were used for thin-layer chromatography (TLC). TLC visualization was accompanied using UV lamp (254 nm) or a charring solution (ethanolic p-anisaldehyde, ethanolic phosphomolybdic acid). 
Analytes. Commercially available antimycin A (Sigma-aldrich, a mixture of $\mathrm{A}_{1}-\mathrm{A}_{4}$ ) was submitted to the evaluation. UK-2A was a generous gift from Meiji Seika Pharma Co., Ltd. Splenocin B was prepared as we have recently reported. ${ }^{12}$ Compounds 4-6 were synthesized by the methods described in our previous report ${ }^{9}$ as shown in Scheme S1.

Isovaleric acid (3S, $4 R, 7 R, 8 R, 9 S)$-[3-(3-hydroxy-4-methoxypiridine-2-carbonyl)-amino7-benzyl-9-methyl-2,6-dioxo-[1,5]dioxonan-8-yl] ester (4). ${ }^{1} \mathrm{H} \mathrm{NMR}\left(600 \mathrm{MHz}, \mathrm{CDCl}_{3}\right) \delta 11.78$ (s, 1H), 8.59 (d, $J=8.2 \mathrm{~Hz}, 1 \mathrm{H}), 7.99(\mathrm{~d}, J=5.2 \mathrm{~Hz}, 1 \mathrm{H}), 7.25(\mathrm{t}, J=7.0 \mathrm{~Hz}, 2 \mathrm{H}), 7.20$ (t, $J=7.3$ $\mathrm{Hz}, 1 \mathrm{H}), 7.13(\mathrm{~d}, J=7.3 \mathrm{~Hz}, 2 \mathrm{H}), 6.87(\mathrm{~d}, J=5.2 \mathrm{~Hz}, 1 \mathrm{H}), 5.35(\mathrm{~m}, 1 \mathrm{H}), 5.23(\mathrm{t}, J=9.8 \mathrm{~Hz}, 1 \mathrm{H})$ $5.17(\mathrm{~m}, 1 \mathrm{H}), 4.97(\mathrm{~m}, 1 \mathrm{H}), 3.94(\mathrm{~s}, 3 \mathrm{H}), 3.62(\mathrm{~m}, 1 \mathrm{H}), 3.00(\mathrm{t}, J=12.6 \mathrm{~Hz}, 1 \mathrm{H}), 2.93(\mathrm{td}, J=2.9$, $11.4 \mathrm{~Hz}, 1 \mathrm{H}), 2.74(\mathrm{~d}, J=13.0 \mathrm{~Hz}, 1 \mathrm{H}), 2.26(\mathrm{~d}, J=7.1 \mathrm{~Hz}, 2 \mathrm{H}), 2.16(\mathrm{sept}, J=6.8 \mathrm{~Hz}, 1 \mathrm{H}), 1.34$ $(\mathrm{d}, J=6.4 \mathrm{~Hz}, 3 \mathrm{H}), 1.00(\mathrm{~d}, J=6.6 \mathrm{~Hz}, 6 \mathrm{H}) ;{ }^{13} \mathrm{C} \mathrm{NMR}\left(150 \mathrm{MHz}, \mathrm{CDCl}_{3}\right) \delta 171.79,171.72$ $169.73,168.95,155.42,148.83,140.70,137.81,129.94,128.75,128.59,126.68,109.70,75.20$, 74.77, 65.25, 56.10, 51.85, 49.98, 43.16, 34.63, 25.46, 22.45, 17.90; HRMS (ESI $\left.{ }^{+}\right) \mathrm{m} / z$ calcd for $\mathrm{C}_{27} \mathrm{H}_{32} \mathrm{~N}_{2} \mathrm{NaO}_{9}[\mathrm{M}+\mathrm{Na}]^{+}$551.20055, found 551.20308; IR (KBr) 3369, 2966, 1749, 1369, 1241, $849,760 \mathrm{~cm}^{-1} ;[\alpha]_{\mathrm{D}}=+83.2\left(\mathrm{c}=0.223, \mathrm{CHCl}_{3}\right)$.

\section{Isobutyric acid (3S, $4 R, 7 R, 8 R, 9 S)$-7-benzyl-3-(3-formylamino-2-hydroxy-benzoylamino)-}

9-methyl-2,6-dioxo-[1,5]dioxonan-8-yl ester (5) was prepared as a 6:1 mixture of rotamers. Major: ${ }^{1} \mathrm{H} \mathrm{NMR}\left(600 \mathrm{MHz}, \mathrm{CDCl}_{3}\right) \delta 12.57$ (s, 1H), 8.65 (d, $\left.J=8.1 \mathrm{~Hz}, 1 \mathrm{H}\right), 8.53$ (dd, $J=1.1$, $8.0 \mathrm{~Hz}, 1 \mathrm{H}), 8.49(\mathrm{~d}, J=1.1 \mathrm{~Hz}, 1 \mathrm{H}), 7.92(\mathrm{~s}, 1 \mathrm{H}), 7.26(\mathrm{t}, J=6.9 \mathrm{~Hz}, 2 \mathrm{H}), 7.21(\mathrm{t}, J=7.8 \mathrm{~Hz}$ 1H), $7.18(\mathrm{dd}, J=1.1,8.1 \mathrm{~Hz}, 1 \mathrm{H}), 7.12(\mathrm{~d}, J=6.3 \mathrm{~Hz}, 2 \mathrm{H}), 6.89(\mathrm{t}, J=8.1 \mathrm{~Hz}, 1 \mathrm{H}), 5.46(\mathrm{~m}, 1 \mathrm{H})$, $5.24(\mathrm{t}, J=9.7 \mathrm{~Hz}, 1 \mathrm{H}), 5.16(\mathrm{~m}, 1 \mathrm{H}), 5.02(\mathrm{~m}, 1 \mathrm{H}), 3.60(\mathrm{~m}, 1 \mathrm{H}), 3.03-2.90(\mathrm{~m}, 2 \mathrm{H}), 2.72(\mathrm{~d}, J$ $=12.1 \mathrm{~Hz}, 1 \mathrm{H}), 2.63(\mathrm{sept}, J=7.0 \mathrm{~Hz}, 1 \mathrm{H}), 1.34(\mathrm{~d}, J=6.4 \mathrm{~Hz}, 3 \mathrm{H}), 1.252(\mathrm{~d}, J=6.9 \mathrm{~Hz}, 3 \mathrm{H})$, $1.246(\mathrm{~d}, J=6.9 \mathrm{~Hz}, 3 \mathrm{H}) ;{ }^{13} \mathrm{C} \mathrm{NMR}\left(150 \mathrm{MHz}, \mathrm{CDCl}_{3}\right) \delta 175.62,171.89,170.06,169.47,158.97$, 
$150.58,137.73,128.74,128.63,127.37,126.76,124.76,120.11,118.93,112.45,75.13,74.91$, 65.88, 52.03, 50.90, 34.53, 34.10, 18.97, 18.96, 17.82; HRMS (ESI ${ }^{+}$) m/z calcd for $\mathrm{C}_{27} \mathrm{H}_{30} \mathrm{~N}_{2} \mathrm{NaO}_{9}$ $[\mathrm{M}+\mathrm{Na}]^{+}$549.18490, found 549.18644; IR (KBr) 3369, 2978, 2937, 1752, 1364, 1242, $740 \mathrm{~cm}^{-}$

${ }^{1} ;[\alpha]_{\mathrm{D}}=+79.6\left(\mathrm{c}=6.54 \times 10^{-3}, \mathrm{CHCl}_{3}\right)$. Minor (diagnostic peaks only): ${ }^{1} \mathrm{H}$ NMR $(600 \mathrm{MHz}$, $\left.\mathrm{CDCl}_{3}\right) \delta 12.41(\mathrm{~s}, 1 \mathrm{H}), 8.77(\mathrm{~d}, J=11.5 \mathrm{~Hz}, 1 \mathrm{H}), 7.74(\mathrm{~d}, J=11.2 \mathrm{~Hz}, 1 \mathrm{H}), 6.87(\mathrm{t}, J=8.0 \mathrm{~Hz}$, $1 \mathrm{H}), 5.23(\mathrm{t}, J=9.0 \mathrm{~Hz}, 1 \mathrm{H}) .{ }^{13} \mathrm{C} \mathrm{NMR}\left(150 \mathrm{MHz}, \mathrm{CDCl}_{3}\right) \delta 160.84,118.78$.

Isobutyric acid $(3 S, 4 R, 7 R, 8 R, 9 S)$-[3-(3-hydroxy-4-methoxypiridine-2-carbonyl)-amino7-butyl-9-methyl-2,6-dioxo-[1,5]dioxonan-8-yl] ester (6) was prepared as a 4:1 mixture of rotamers. Major: ${ }^{1} \mathrm{H}$ NMR $\left(600 \mathrm{MHz}, \mathrm{CDCl}_{3}\right) \delta 11.09(\mathrm{~s}, 1 \mathrm{H}), 8.65(\mathrm{~d}, J=8.1 \mathrm{~Hz}, 1 \mathrm{H}), 8.01(\mathrm{~d}, J$ $=5.2 \mathrm{~Hz}, 1 \mathrm{H}), 6.89(\mathrm{~d}, J=5.2 \mathrm{~Hz}, 1 \mathrm{H}), 5.48(\mathrm{br} \mathrm{s}, 1 \mathrm{H}), 5.19(\mathrm{~m}, 1 \mathrm{H}), 5.07(\mathrm{t}, J=9.9 \mathrm{~Hz}, 1 \mathrm{H})$, $4.94(\mathrm{~m}, 1 \mathrm{H}), 3.95(\mathrm{~s}, 3 \mathrm{H}), 3.76(\mathrm{~m}, 1 \mathrm{H}), 2.61(\mathrm{sept}, J=7.0 \mathrm{~Hz}, 1 \mathrm{H}), 2.58(\mathrm{td}, J=2.9,13.0 \mathrm{~Hz}$, 1H), $1.72(\mathrm{~m}, 1 \mathrm{H}), 1.28(\mathrm{~d}, J=8.3 \mathrm{~Hz}, 3 \mathrm{H}), 1.38-1.09(\mathrm{~m}, 5 \mathrm{H}), 1.217(\mathrm{~d}, J=6.9 \mathrm{~Hz}, 3 \mathrm{H}), 1.211$ $(\mathrm{d}, J=6.9 \mathrm{~Hz}, 3 \mathrm{H}), 0.86(\mathrm{t}, J=7.0 \mathrm{~Hz}, 3 \mathrm{H}) ;{ }^{13} \mathrm{C} \mathrm{NMR}\left(150 \mathrm{MHz}, \mathrm{CDCl}_{3}\right) \delta 175.55,172.67,169.73$, $168.98,155.43,148.84,140.71,129.97,109.71,75.17,74.90,65.12,56.10,52.06,50.03,34.09$, 29.17, 28.06, 22.33, 18.93, 18.91, 17.77, 13.73; HRMS (ESI') $m / z$ calcd for $\mathrm{C}_{23} \mathrm{H}_{31} \mathrm{~N}_{2} \mathrm{O}_{9}[\mathrm{M}-\mathrm{H}]^{-}$ 479.20295, found 479.20270; IR $(\mathrm{KBr}) 3100,2937,1751,1284,1240,810 \mathrm{~cm}^{-1} ;[\alpha]_{\mathrm{D}}=+71.1(\mathrm{c}$ $\left.=2.73 \times 10^{-1}, \mathrm{CHCl}_{3}\right)$. Minor (diagnostic peaks only): ${ }^{1} \mathrm{H} \mathrm{NMR}\left(600 \mathrm{MHz}, \mathrm{CDCl}_{3}\right) \delta 5.14($ br s, $1 \mathrm{H}), 4.80(\mathrm{~m}, 1 \mathrm{H}), 3.41(\mathrm{~m}, 1 \mathrm{H}), 2.51(\mathrm{td}, \mathrm{J}=2.9,11.2 \mathrm{~Hz}, 1 \mathrm{H}) ;{ }^{13} \mathrm{C} \mathrm{NMR}\left(150 \mathrm{MHz}, \mathrm{CDCl}_{3}\right) \delta$ 75.24, 74.20, 66.99, 49.85 . 
Cell culture. RBL-2H3 cells (Health Science Resources Bank, Osaka, Japan) were cultured in Dulbecco's modified Eagle's medium (Sigma, St. Louis, MO, USA) supplemented with 10\% fetal bovine serum (Life Technologies, CA, USA), $100 \mathrm{U} / \mathrm{mL}$ penicillin, and $100 \mu \mathrm{g} / \mathrm{mL}$ streptomycin (Sigma) as a growth medium at $37^{\circ} \mathrm{C}$ under $5 \% \mathrm{CO}_{2}$.

Measurement of $\mathbf{I L}-4$ released from cells. RBL-2H3 cells were inoculated into a 96-well plate $\left(2.5 \times 10^{4}\right.$ cells/well $)$ and cultured overnight. The cells were further incubated in a growth medium containing $50 \mathrm{ng} / \mathrm{mL}$ of DNP-IgE (Sigma) for $2 \mathrm{~h}$. After washing with the growth medium, each drug in $N, N$-dimethylformamide ( $0.05 \%$ final concentration) was added to the culture. After incubation for $10 \mathrm{~min}$, DNP-labeled human serum albumin (50 $\mathrm{ng} / \mathrm{mL}$ final concentration, Sigma) was added and the culture were incubated for $1 \mathrm{~h}$. The release levels of IL-4 in the supernatant were measured using Rat IL-4 Platinum ELISA (Invitrogen BMS628), and the multiplex immunoassay Luminex 200 system (Luminex, Co, TX, USA).

Cytotoxicity assay. RBL-2H3 cells were seeded on 96-well plates at an initial density of $10^{5}$ cells per well and incubated under $5 \% \mathrm{CO}_{2}$ for $12 \mathrm{~h}$ at $37^{\circ} \mathrm{C}$. After incubation, RBL-2H3 cells were further incubated in Dulbecco's modified Eagle's medium with each drug for $24 \mathrm{~h}$. The medium was then replaced with a $100 \mu \mathrm{L}$ of the culture medium containing serum. For the detection of relative cell viability, a Cell Counting Kit-8 (Dojindo molecular technologies, $10 \mu \mathrm{L}$ ) solution was added into each well of the 96-well plate containing a completely water-soluble tetrazolium salt WST-8 [2-(2-methoxy-4-nitrophenyl)-3-(4-nitrophenyl)-5-(2,4-disulfophenyl)$2 \mathrm{H}$-tetrazolium, monosodium salt] was reduced by dehydrogenase in living cells to give an orange colored outcome, WST-8 formazan, which was also soluble in the cell medium. The quantity of the formazan was directly proportional to the amount of living cells after $1 \mathrm{~h}$ incubation, and results were obtained by a microplate reader at $450 \mathrm{~nm}$. 
Table 1. Effects of compounds 4-6 on anti-inflammatory cytokine IL-4 release.

$\begin{array}{cc}\text { Compound } & \mathrm{IC}_{50}(\mathrm{nM}) \text { for IL-4 release } \\ \mathbf{4} & 4386 \\ \mathbf{5} & 41.3 \\ \mathbf{6} & - \text { N.C. }\end{array}$

The release levels of IL-4 were evaluated using DNP-IgE-stimulated RBL-2H3 cells. Statistical analyses and the calculation of IC $_{50}$ values were performed using GraphPad Prism 5.02 (GraphPad Software, San Diego, CA) based on the data in Figure S1. N.C. indicates that $\mathrm{IC}_{50}$ value could not be calculated, but the maximum restriction was observed at $1000 \mathrm{nM}$ (Figure S1).
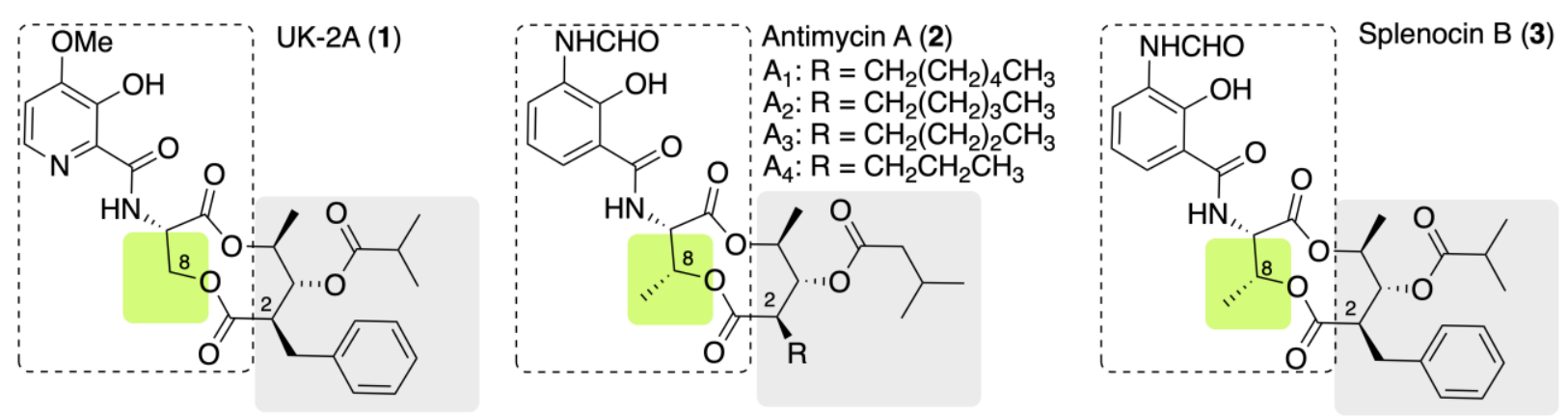

Figure 1. Structures of UK-2A, antimycin A, and splenocin B. 
A

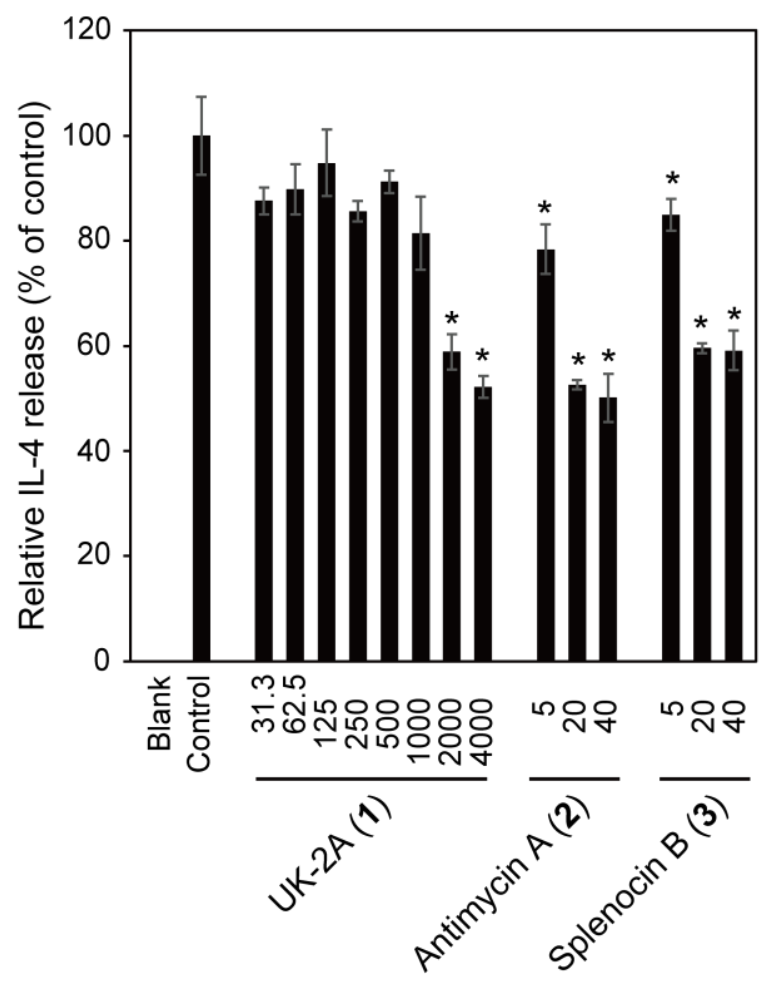

B

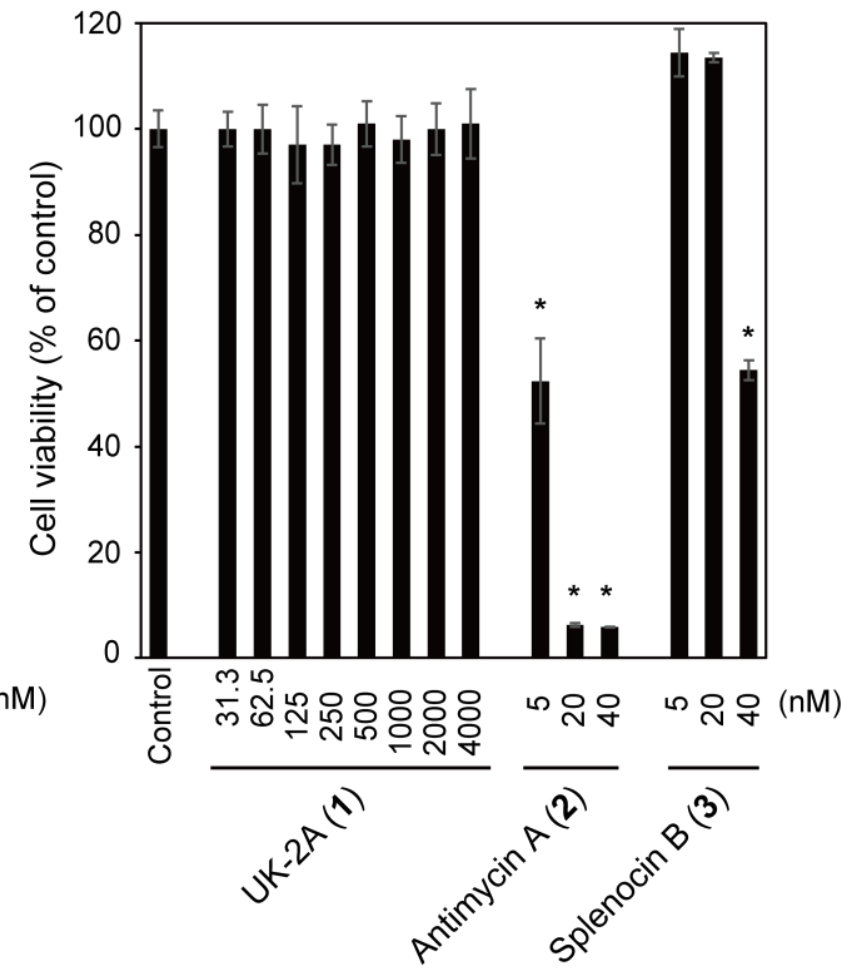

Figure 2. Effects of compounds 1-3 on anti-inflammatory cytokine IL-4 release (A) and RBL$2 \mathrm{H} 3$ cell viability (B). The release levels of IL-4 (A) were evaluated using DNP-IgE-stimulated RBL-2H3 cells. Results are expressed as a mean value \pm standard error of mean $(n=3)$. Cell viability (B) was evaluated after the cells were incubated in Dulbecco's modified Eagle's medium containing each drug at $37^{\circ} \mathrm{C}$ for $24 \mathrm{~h}$. Results are expressed as a mean value \pm standard error of mean $(n=4)$. The asterisk indicates significant differences against the control based on Student's $t$-test, where data with $p<0.05$ were considered to be statistically significant.
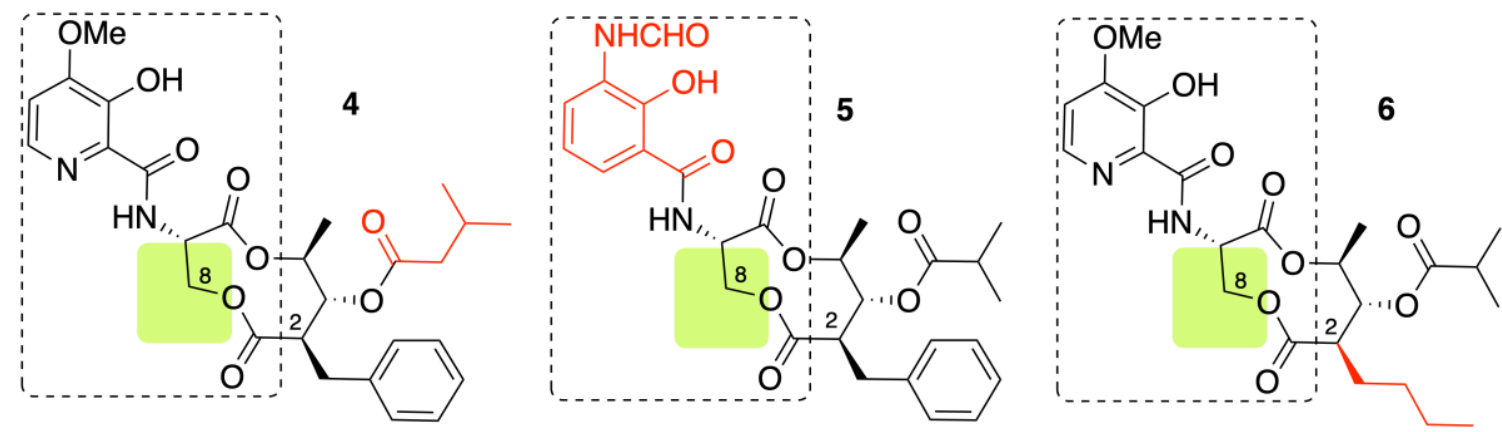

Figure 3. Structures of synthesized hybrid molecules (4-6) combining some structural features of UK-2A and antimycin $A_{3}$. The moiety from antimycin $A_{3}$ is indicated in red. 


\section{ASSOCIATED CONTENT}

Supporting Information. The following file is available free of charge.

Synthetic route, 1D NMR spectra $\left({ }^{1} \mathrm{H}\right.$ and $\left.{ }^{13} \mathrm{C}\right)$ of 4-6, effects of UK-2A (1) and compounds 4-6 on anti-inflammatory cytokine IL-4 release, effects of compounds 4-6 on RBL-2H3 cell viability (PDF).

\section{AUTHOR INFORMATION}

\section{Corresponding Author}

*E-mail (Y. Usuki): usuki@sci.osaka-cu.ac.jp.

* E-mail (K.-I. Fujita): kfujita@ sci.osaka-cu.ac.jp.

\section{ORCID}

Yoshinosuke Usuki: 0000-0003-2308-8693

Ken-Ichi Fujita: 0000-0001-8496-7435

\section{Notes}

The authors declare no competing financial interest.

\section{Acknowledgment}

This manuscript is dedicated to the memory of the late emeritus Professor Makoto Taniguchi, Osaka City University. We also thank Dr. Matsumi Doe, Analytical Division, Osaka City University, for 2D NMR measurements. The present research was supported in part by the Osaka City University (OCU) Strategic Research Grant 2017 for top priority research, which is greatly appreciated. 


\section{References}

(1) Ueki, M.; Abe, K.; Hanafi, M.; Shibata, K.; Tanaka, T.; Taniguchi, M. J. Antibiot. 1996, 49, 639-643.

(2) Hanafi, M.; Shibata, K.; Ueki, M.; Taniguchi, M. J. Antibiot. 1996, 49, 1226-1231.

(3) Ueki, M.; Taniguchi, M. J. Antibiot. 1997, 50, 1052-1057.

(4) Shibata, K.; Hanafi, M.; Fujii, J.; Sakanaka, O.; Iinuma, M.; Ueki, M.; Taniguchi, M. J. Antibiot. 1998, 51, 1113-1116.

(5) Strangman, W. K.; Kwon, H. C.; Broide, D.; Jensen, P. R; Fenical, W. J. Med. Chem. 2009, 52, 2317-2327.

(6) Chang, C.; Huang, R.; Yan, Y.; Ma, H.; Dai, Z.; Zhang, B.; Deng, Z.; Liu, W.; Qu, X. J. Am. Chem. Soc. 2015, 137, 4183-4190.

(7) Li, H.; Huang, H.; Hou, L.; Ju, J.; Li, W. Front. Microbiol. 2017, 8, 678.

(8) Usuki, Y.; Tani, K.; Fujita, K.-I.; Taniguchi, M. J. Antibiot. 2001, 54, 600-602.

(9) Usuki, Y.; Goto, K.; Kiso, T.; Tani, K.; Ping, X.; Fujita, K.-I.; Taniguchi, M. J. Antibiot. 2002, 55, 607-610.

(10) Fujita, K.-I.; Kiso, T.; Usuki, Y.; Tanaka, T.; Taniguchi, M. J. Antibiot. 2004, 57, 687690.

(11) Usuki, Y.; Mitomo, K.; Adachi, N.; Ping, X.; Fujita, K.-I.; Sakanaka, O.; Iinuma, K.; Iio, H.; Taniguchi, M. Bioorg. Med. Chem. Lett. 2005, 15, 2011-2014. 
(12) Yoshida, K.-I.; Ijiri, M.; Iio, H.; Usuki, Y. Tetrahedron 2015, 71, 9626-9629.

(13) Barnes, P. J. Nat. Rev. Immunol. 2018, 18, 454-466.

(14) Sewell, W. A.; Scurr, L. L.; Orphanides, H.; Kinder, S.; Ludowyke, R. I. Clin. Diagn. Lab. Immunol. 1998, 5, 18-23.

(15) Horigome, S.; Yoshida, I.; Tsuda, A.; Harada, T.; Yamaguchi, A.; Yamazaki, K.; Inohana, S.; Isagawa, S.; Kibune, N.; Satoyama, T.; Katsuda, S.; Suzuki, S.; Watai, M.; Hirose, N.; Mitsue, T.; Shirakawa, H.; Komai, N. Biosci. Biotechnol. Biochem. 2014, 78, 851-860.

(16) Li, N.; Zhang, W.; Khan, M.; Lin, L.; Lin, J. M. Biosens. Bioelectron. 2018, 99, 142-149.

(17) Kim, C. H.; Lee, T.; Oh, I.; Nam, K. W.; Kim, K. H.; Oh, K. B.; Shin, J.; Mar, W. Biol. Pharm. Bull. 2013, 36, 339-345.

(18) Tzung, S. P.; Kim, K. M.; Basañez, G.; Giedt, C. D.; Simon, J.; Zimmerberg, J.; Zhang, K. Y.; Hockenbery, D. M. Nat. Cell Biol. 2001, 3, 183-191.

(19) Formentini, L.; Santacatterina, F.; Núñez de Arenas, C.; Stamatakis, K.; López-Martínez, D.; Logan, A.; Fresno, M.; Smits, R.; Murphy, M. P.; Cuezva, J. M. Cell. Rep. 2017, 19, 12021213.

(20) Holmbeck, M. A.; Shadel, G. S. Nat Immunol. 2016, 17, 1009-1010.

(21) Garaude, J.; Acín-Pérez, R.; Martínez-Cano, S.; Enamorado, M.; Ugolini, M.; NistalVillán, E.; Hervás-Stubbs, S.; Pelegrín, P.; Sander, L. E.; Enríquez, J. A.; Sancho, D. Nat. Immunol. 2016, 17, 1037-1045. 
(22) Ghassemi-Rad, J.; Maleki, M.; Knickle, A. F.; Hoskin, D. W. Cell Biol. Int. 2018, 42, 1069-1075. 